\title{
Globalization and the Crisis in Detroit
}

\author{
Gail M. Presbey, University of Detroit Mercy
}

\section{Introduction: Background of a City in Crisis}

Detroit has been in the news recently, because it has become the largest municipality to declare "Chapter 9" bankruptcy in the United States. The city's Emergency Manager Kevyn Orr filed for bankruptcy on July 18, 2013. How did the city get an "Emergency Manager"? How did the city get into such financial trouble? What have activists been doing to challenge these developments?

Michigan's Republican Governor Rick Snyder has placed emergency managers in many cities across the state. According to state guidelines, over 150 municipalities in Michigan are eligible for emergency manager appointments. State treasury representatives said in 2012 that they had 68 municipalities and an equal number of school districts in the state on their "watch list." An emergency manager has power to make all financial decisions, nullifying the decisions of elected leaders such as mayors, city councils, planning commissions, zoning boards, and police commissioners. Currently most African Americans in Michigan live in a locale ruled by an emergency manager that they did not elect. Michigan citizens repealed the Emergency Manager law in an election in November 2012. Fifty-two percent of the state's residents, including 82 percent of Detroit voters, voted to take away the governor's right to impose an emergency manager. But soon after the repeal the governor drafted a new emergency manager

This is a pdf copy of the author's peer-reviewed version of "Globalization and the Crisis in Detroit." The version of record appears in Perspectives on Global Development and Technology 15, Nos. 1-2 (2015): 261-277. https://doi.org/10.1163/15691497-12341344

(C) 2019 Gail M. Presbey. Used with permission. 
law, Public Act 436, which could not be repealed because it was tied to the budget. This is a technicality that Snyder has used often to make his new laws unassailable.

What is the larger crisis? Many cities are in debt. The governor and his allies are suggesting that the cause of that debt is mismanagement by elected officials, largely African American, and by too-generous contracts to city employees. But critics say the problems are caused by corporations, banks and realtors, and their racist practices. They note that while emergency managers are touted as fiscally responsible, they get paid high salaries — higher even than elected officials. Emergency managers can approve contracts that give business opportunities to their friends, and they often make unwise investments or sell off city assets for a fraction of their worth. While emergency managers are allowed to break union contracts and lay off workers, they often add new expenses in other areas so that they do not end up being fiscally responsible("True Facts" 2013: 5).

In the case of Detroit, problems are long in the making. Earlier, people flocked to the area for jobs in the automotive industry. Detroit was home to the sit-down strikes in 1936 and 1937 that won better pay, better working hours, and safer working conditions for factory workers. Auto company executives and management responded by relocating plants elsewhere and by turning to automation to eliminate jobs. Detroit's population started shrinking in the 1950s. From its high of about two million, the population shrunk to about 700,000 in 2014.

The auto industry, which back in Detroit's heyday in the 1940s provided some of the highest wages for blue collar workers, currently locates its production plants around the world. General Motors (GM), for example, sold more than 2.26 million cars in China in 2014 and carries out widespread manufacturing there (Maithya 2014). Globalized assembly of cars started decades 
ago when GM and Ford established plants in Australia, Europe, and Asia. Now it is usually the case that even these "American"-brand cars are at least partially assembled in other countries.

Gary Chaison notes that globalization has had a huge impact on the auto industry, as now some foreign car makers are partly owned by the Big Three automakers, while one of the three, Chrysler, is now majority-owned by Fiat, an Italian-based company (Hammonds 2009; Chaison 2014: 1-2). Auto manufacturers started moving production first to the southern U.S. and then to Mexico in search of cheaper labor in the 1970s and '80s. ${ }^{*}$ Miller and Sirgy note that while Detroit remains the "hub" of the auto industry in the U.S., in fact there is now a North-South corridor with assembly and supplier plants found in Ohio, Kentucky, Tennessee, and many other southern states. Many of these southern facilities are foreign-owned (Miller and Sirgy 2011).

While auto companies open and close plants around the world, the impact on Detroit residents has been profound. Chrysler still has its Conner Avenue assembly plant (opened in 1966) as well as its Jefferson North plant, Mack Avenue Engine complex, and Mount Elliot Tool and Die plant. But it has closed many other plants, such as Detroit Axle (open from 1912 to 2010), Dodge Main (1914-1980), Jefferson Avenue Assembly (1907-1990), and Mound Road Engine (1953-2002) (Wikipedia 2014). The problem of declining sales and lower production, leading to layoffs and factory closings, affected all three companies across the entire U.S., not only Detroit. The U.S. auto industry had reached its peak employment level in 2000, employing 1,313,600 workers. That number began to fall drastically during the following decade. Foreign-

\footnotetext{
*While news headlines recently heralded GM's decision to begin manufacturing the Cadillac SRX in Spring Hill, Tennessee, shifting production from its current location in Ramos Arizpe, Mexico, news sources note the lesstouted information that the Chevrolet Equinox, currently manufactured at Spring Hill, will soon be manufactured at Ramos Arizpe. The net gain of jobs for Spring Hill could be largely offset by the lost jobs on the Chevy Equinox. Automotive News notes as well that GM's willingness to relocate some manufacture in Tennessee is only because the UAW agreed to concessions that included a two-tier wage system, so that new employees will be paid a lower amount. (Woodall and Lienert 2014).
} 
affiliated manufacturers were hiring more workers, but not at a rate that offset job losses from the Big Three (U.S. Department of Commerce 2005).

Plant closings can't fully explain what Thomas Sugrue noticed and analyzed in his 1996 classic, The Origins of the Urban Crisis: Race and Inequality in Postwar Detroit. Looking at the "rust belt" that has formed in many U.S. cities, such as Chicago, Cleveland, the South Bronx, Gary, Pittsburgh, Camden, Newark, and Baltimore, one can't help but notice that "Central city residence, race, joblessness and poverty have become inextricably intertwined in postindustrial urban America" (Sugrue 1996:3). His study shows that deindustrialization began in the 1950s with several key auto plants in Detroit closing and people abandoning the adjacent neighborhoods. In the ensuing decades, politicians built public housing projects in the city while subsidizing white suburbanization, reinforcing racial segregation and leaving the city with fewer local employment opportunities. Industries relocated not only due to technological innovation, improved communications and transportation, but also due to their wish to avoid unionized workers and taxes, as well as to be near new markets (Sugrue 1996:10-11, 125-26). In fact, Gary Chaison argues, auto companies' decisions to relocate have undercut the ability of workers to bargain collectively and so has led to the collapse of Detroit's economy (Chaison 2014:1). But this is only part of the story.

During the last half of the twentieth century, Sugrue notes, bureaucratization and technology reduced the need for assembly line workers and changed the white collar to blue collar auto job ratio from 26 for every 100 to 63 for every 100. These professional and managerial jobs went primarily to white workers (Sugrue 2004). These trends led to a highly impoverished African American city population surrounded by majority-white, more affluent suburbs. George Galster claims that most researchers or journalists who study Detroit focus on the city itself out of 
context with its surrounding suburban metro area. He asserts that the problems of unemployment and poverty in the city are often results of decisions made by suburban actors, since the suburbs, the "primary" albeit "reckless" drivers of the regional economy, don't have the entire region's needs and well-being in mind (Galster 2012:x). All of this serves as a half-a-century backdrop to the current crisis, which began with gusto in 2008 .

\section{Housing, Segregation, and the Mortgage Crisis in Detroit}

Detroit was particularly hard hit by the mortgage crisis in 2008. Studies have shown that the worst mortgage rates (sub-prime loans) were disproportionately given to African Americans and other U.S. racial minorities. Over 100,000 properties were foreclosed in Detroit over the last ten years. The city's emergency manager, Kevyn Orr, worked for the law firm Jones Day, which represents Bank of America, a key mortgage lender and a key cause of many foreclosures. Orr used his power as emergency manager to award Jones Day a multi-million dollar consulting contract for the city. Reverend Bill Wylie-Kellerman, who with Elena Herrada was arrested for protesting the awarding of that contract by sitting in and disrupting the City Council meeting that day, explained in his statement to the court during his trial for civil disobedience that he was concerned that in bankruptcy proceeding Bank of America would get 75 cents on the dollar for what the city owes, while pensioners were offered ten cents on the dollar (Kiertzner 2013).

It is interesting to note that programs President Obama passed to deal with the 2008 mortgage crisis used taxpayer's dollars to bail out not the families stuck in foreclosure, but the banks, who are reimbursed the full price of the mortgage for any foreclosed house. This deal effectively discourages banks from helping financially distressed families hold onto their houses 
by refinancing at better interest rates. At the same time it sticks taxpayers with paying for the risks that the mortgage companies took on by making the loans in the first place.

Recent developments hold out some promise for redressing the wrongdoing engaged in by some mortgage banks. The U.S. Department of Justice recently reached a \$16.64 billion civil settlement with Bank of America and its subsidiaries Countrywide and Merrill Lynch. This payment is due to its practice of defrauding investors by repackaging risky subprime mortgages into securities that were then sold to federally backed financial institutions. The settlement will provide $\$ 4.6$ billion for remediation payment and $\$ 7$ billion for relief to struggling homeowners. But this relief will not be felt by the many who already lost their Detroit homes to foreclosure in the years since the 2008 mortgage crisis began. What the banks will be able to count as homeowner "relief" mostly will be lowering principal payments, as well as "writing new loans in distressed areas, donating foreclosed properties to community groups, and temporarily suspending payments on some loans"(Yost and Gordon 2014). Such activities will not restore lost properties to homeowners who have already been foreclosed and dispossessed.

The subprime mortgage practices are only the latest version of a longstanding problem with racism in real estate. Due to racism, an African American family that buys a house is in the unique situation of devaluing their purchase by the mere fact that they are moving in, since in a context of racism, houses in African American neighborhoods have a lowered demand and so a lower value. Houses of similar structure and quality in black neighborhoods have lower market values than the same houses in white neighborhoods. This racism reflected in the market value of homes is a barrier to African American families' accumulation of wealth to pass on to their family members. As a Brandeis longitudinal study of twenty-five years' duration shows, while the income gap between African Americans and white Americans slightly improved, the wealth 
gap tripled, due primarily to differences in home ownership and valuation. As they explain, "residential segregation artificially lowers demand, placing a forced ceiling on home equity for African Americans who own homes in non-white neighborhoods." They also struggle more to buy homes in the first place due to difficulty obtaining credit and lack of family assistance (inheritance or otherwise) for down payments (Shapiro et al. 2013:3). While white Americans who go to their former neighborhoods often complain that the houses there are deteriorating, chances are that in their neighborhoods it makes financial sense to invest in upkeep and upgrading of their houses, which usually appreciate in value. It is hard to justify such expenses in black neighborhoods on economic grounds, because chances are houses will lose their value, and costly improvements may not be financially recouped upon sale of the house.

Studies have shown that African American homebuyers are given worse interest rates than whites of a similar credit rating and income. ${ }^{*}$ Part of Detroit's dwindling tax base is due to the devaluation of properties. Detroit's houses are worth less than half of what they were just five years ago, and the revenue from property taxes has lessened in turn. Another problem leading to the budget shortfall is that about 44 percent of Detroit properties are in arrears in paying their taxes, often because banks will not pay property tax on their foreclosed properties.

A 2010 report called the Fiscal Condition of the City of Detroit, quoted by the University of Detroit Mercy Detroit Collaborative Design Center says: “There are 33,529 vacant single or multiple family housing units and ... 91,488 (26 percent) of the city's 343,849 residentially zoned lots have no buildings on them ... Between 1992 and 2002, Detroit lost 39 percent of its manufacturing establishments ... The city was recently declared a food desert, an area that has

\footnotetext{
* There are good studies that show how the recent housing crisis was greatly affected by racism. Bocian et al. 2011 says one third of African American homeowners in Detroit are in foreclosure. Another study, Rugh and Massey 2010, is sponsored by Princeton University.
} 
low-to-no access to healthy, fresh, affordable food, an area of 'relative exclusion where people experience physical and economic barriers to accessing healthy food' ... The unemployment rate is over twice that of the state. It more than doubled between 2000 and 2008, and nearly doubled again between 2008 and August 2009. Nearly one-third of residents and more than half of Detroit families with children live at or below poverty"(Wozniak n.d.:7). "The city has been left with approximately 40 square miles of unproductive, vacant land. . . Unemployment in Detroit currently exceeds 30 percent. Only one in 44 persons eligible for drug treatment are provided with it" (Woznizk n.d.:7).

\section{Detroit's Bankruptcy}

While Detroit may be famous for the extent of its problems, it's important to realize that the city is not an anomaly. "Detroit is 32 nd in a long list of 374 cities worldwide that have sustained a shrinking population over a 50-year period. There are 59 cities in the United States alone" (Wozniak n.d.:13).

And while coverage of the bankruptcy often mentions that Detroit is $\$ 18.5$ billion in debt, much of that debt is due to agreements with wealthy business investors who talked city officials into investing in large, expensive projects, including stadiums and incinerators among others. Often officials agreed to such projects, hoping that they would revitalize the city and help its economy. Many think that some of those business investments will still be solvent in the long run, but other investments (like the incinerator, which causes high asthma rates) never should have been agreed to in the first place. Similar-size projects that would create jobs in the city would give taxpayers more tangible results from their investments. 
Another problem is that property taxes can't cover the city's operational costs. But there's a story behind that predicament: the city is not able to borrow money at good interest rates. The bankruptcy has just exacerbated this problem, because as a recent news article notes, "Anticipating the filing, investors drove prices of Detroit bonds and notes lower, sending their yields to record highs on Thursday ..."(Carey 2013). A study by the Service Employees International Union (SEIU) notes that the city has become locked into high interest rates, which account for about $\$ 100$ million per year. Orr has said that in 2013 Detroit will pay \$139 million in interest on its debts. Critics of the emergency manager note that if Detroit had been given a good interest rate, it wouldn't be in this crisis it is now ("True Facts" 2013:5).

It seems particularly unfair that city pensioners are made to suffer in the bankruptcy deal. Investigative reporter Curt Guyette was able to uncover that two Jones Day lawyers, Jeffrey B. Ellman and Daniel J. Merrett, published an article in a law journal in 2011 suggesting that, if municipalities were to declare bankruptcies, they might be able to shed much of their pension obligations (Ellman and Merret 2011). According to Guyette, there is reason to believe that Kevyn Orr, an employee of Jones Day, a firm that specialized in bankruptcies, was chosen as the emergency manager for Detroit because Snyder foresaw and even wished that Detroit would declare bankruptcy in order to lessen pension obligations. But is negotiating away people's pensions, paying them only a fraction of what they thought they were due, fair? Guyette argues that, "The people receiving these pensions, after all, made irreversible career choices based on those promises, which they believed were etched in stone, and fulfilled their end of the bargain through decades of labor that can never be recouped."(Guyette 2014: 26).

Detroit pensioners were pressured in July of 2014 to vote to accept cuts to their own pensions to prevent the sale of art from the Detroit Institute of Arts collection as well as to avoid possible 
larger cuts to their pensions. Pensioners in Flint and Pontiac are likewise trying to defend their pensions from emergency managers assigned to those cities. Investigative journalist David Sirota claims that certain nonprofits are misleading the public by claiming that it is pension obligations, rather than the more expensive corporate subsidies, that are causing the crisis of municipalities living beyond their means. He specifically notes that "The Pew Charitable Trusts and the Laura and John Arnold Foundation are working together in states across the country to focus the debate over pensions primarily on slashing retiree benefits rather than on raising public revenues" (Sirota n.d.).

Holding a very different view, Detroit Free Press investigative reporters place the blame on Detroit's elected officials who, decades earlier, refused to cut the city's workforce to a size it could afford and then offered that workforce pensions and other benefits, including health care and bonuses, it couldn't fund (Bomey and Gallagher 2013). Now folks at the Detroit Free Press are suggesting that, because past elected mayors of Detroit hadn't scaled back their employees to a level that hindsight required, the current pensioners who already spent their lives working for the city will have their contracts reneged upon and live their elder years in destitution. Such an argument can't stand up to Guyette's charge quoted above. And the double standard — where the federal government is required to bail out banks and mortgage companies, but doesn't have to help municipalities in financial trouble - is glaring.

While thousands of Detroiters struggle to survive unemployment and lack of city services, Detroit's crisis provides opportunities with those who have the money to buy the city's riches and resources at rock-bottom prices. A New York Times correspondent recently noted that in Detroit, "property costs have dropped to the point that barriers to ownership - to a sort of mogulhood, even - are absurdly low" (Austen 2014). Some people are becoming moguls, such 
as billionaire Dan Gilbert, owner of Quicken Loans and sixty downtown buildings. Last year a dozen buyers each bought over 100 houses that had been in foreclosure. Some large investors, like Gary Alexander and Siegel Clore, are African-American. Others are Chinese, including those who bought the art deco-style David Stott Building (Austen 2014).

Even the New York Times has noticed that young people, mostly white college graduates, are flocking to the downtown area of Detroit, not only because cost of living is so affordable compared to other big cities, but also because of opportunities. It is relatively easy to open up your own business, so easy the Times article exclaims, that "the city seems like a giant candy store for young college graduates wanting to be their own bosses"(Conlin 2011). The nonprofit Hudson Webber Foundation has started a project called " 15 by 15 " whose goal is to attract 15,000 young, talented households to the downtown area by 2015 . While this revitalizes the downtown area, it neglects the vast majority of African American residents' needs for city services and job opportunities.

\section{Resistance and Community Organizing}

As Detroiters suffer from lack of democratic representation, with the purse strings of their city controlled by an un-elected emergency manager, some dedicated activists have prophetically spoken out against the situation. As mentioned above, Rev. Bill Wylie-Kellerman, a Methodist pastor of St. Peter's Episcopal Church, and Elena Herrada, an elected Detroit School Board member, disrupted a meeting of the Detroit City Council on April 16, 2013, as an act of purposeful civil disobedience. Their protest came the day that the council was going to vote on a controversial city contract that would hire Jones Day, the law firm that had formerly employed 
Kevyn Orr, Detroit's emergency manager, to handle the city’s finances. Jones Day is paid \$1000 an hour as consultants to the city. Estimates suggested that processing the city's bankruptcy will cost the city about $\$ 100$ million, the majority of that money going to Jones Day.

Isn't it a conflict of interest for the emergency manager to hire his former (and possibly future) employer to get the city's most lucrative contract? Wylie-Kellerman and Herrada thought so. Since their protest and arrest they have only become more concerned with how the emergency manager is going to shield the banks that made predatory mortgage loans and now lend Detroit's money to rich investors, while the poorest and most vulnerable citizens may be forced to move as city services cease in their neighborhoods.

Wylie-Kellerman and Herrada's court date was set for January 27, 2014, but the charges were subsequently dropped. Wylie-Kellerman said with some frustration, "We were to answer misdemeanor charges for disrupting City Council on the vote of the Jones Day Contract. It coincided ironically with the fiftieth anniversary of Dr. King's Letter from a Birmingham Jail. Charges were dismissed by Judge Kenneth King in $36^{\text {th }}$ district court . . . to be honest, I'm . . . disappointed we didn't get a chance to put before a jury our justification for that outburst of truth telling."

Wylie-Kellerman is not cured of his impetus to speak truth to power. He has been attending the court proceedings related to the bankruptcy. He mentioned that only about a dozen members of the general public had been attending with any regularity_retired city employees and folks who work for the water department, for example. In early January 2014 the court discussed whether they should borrow $\$ 350$ million from Barclay’s to pay off Bank of America, which was charging a higher interest rate. Wylie-Kellerman said he hadn't planned speaking out, but that he 
was open to the Holy Spirit if it would move him to speak. On January 7, when Kevyn Orr was on the witness stand with his bodyguard, it did. Wylie-Kellerman, irked by the way in which the judge referred repeatedly to Jones Day as "the city," stood up and shouted "Jones Day is not the City of Detroit, and neither is Kevyn Orr" (Bukowski 2014). The judge fled the courtroom, and Wylie-Kellerman was escorted out. That particular day he was not arrested.

Wylie-Kellerman and others at Detroiters Resisting Emergency Management intend to continue their prophetic witness, defending the rights of Detroiters to determine their own destiny. Speaking to a large audience at Marygrove College on February 25, 2014, WylieKellerman highlighted continued dissatisfaction with the bankruptcy proposal presented to the public the week before. Kevyn Orr's "structural adjustment plan" for the city calls for half a billion dollars for blight removal. But the Blight Authority is funded and run by corporate interests. He also took to task non-profit organizations that want to plan for the city's future while bypassing elected government. He bemoaned the "spiritual disinvestment" of the Catholic Archdiocese, which has been closing many of its churches and social services operations within the city. The role that predatory loans and foreclosure played has not even been addressed by the restructuring plan. The organization which he supports, Detroiters Resisting Emergency Management, unveiled their own People's Plan for restructuring, which involves charging the banks for their role in the city's destruction.

Another group active in resistance is the Boggs Center to Nurture Community. The group was started by Grace Lee Boggs, longtime Detroit resident and activist, who was married to activist Jimmy Boggs. Trained as a philosopher, Boggs has written several books whose focus is always the need to forge new communities and renew relationships. She saw a need to completely rethink what lives are all about. Living simply, she rejects the idea that our lives 
should be about holding down a job and paying our bills. She argues that we need a better model of human flourishing (Boggs 2011:70-71).

In these troubling times, it may be that Boggs' dual advice to critique and fight the powers that be, while building community and alternative lifestyles, is a good direction in which to proceed. In the meantime we really do need a revolution of thinking, values, and living. We have to cure our hearts and our institutions of racist practices instead of disinvesting in cities, making them harder to live in and less able to get government funds. Instead of considering inhabitants expendable, we need to reinvest in cities, bringing quality education and employment opportunities to those who live there. But cities need more than money alone. Cities need the flowering of its members' creativity and community built among them.

\section{Water Woes}

No account of Detroit's woes could be complete without mentioning shutoffs of water to about 18,000 homes in Detroit this past summer of 2014. Households were shut off for due bills as little as $\$ 150$, and they were often not given clear notice or warning of shutoff procedures. Why go after these households that are in arrears, mostly with rather small bills, with such drastic methods? Speculation is rampant that the main impetus was to make the Water Department look profitable to private investors. Yet choosing to go after the poorest households in Detroit created a humanitarian disaster, and according to the United Nations, deprived Detroiters of their human right to water. Catarina de Albuquerque, a U.N. Special Rapporteur on the right to safe drinking water and sanitation, said that "when there is genuine inability to pay, human rights simply forbids disconnections." Leilani Farha, another U.N. Special Rapporteur, 
stated that "if these water disconnections disproportionately affect African Americans they may be discriminatory, in violation of treaties the U.S. has ratified"'(Abbey-Lambertz 2014).

Professor Shea Howell from Oakland University, herself active in the Boggs Center and involved in resisting Detroit's emergency management, explained the situation. Emergency Manager Kevyn Orr decided to pay $\$ 5.7$ million to a company called Homrich to collect on unpaid debts. "By their own admission, Homrich had neither the expertise nor the inclination to go after large corporate debtors. Orr chose to attack thousands of residents rather than going after a small number of corporate and commercial accounts. These accounts owe nearly half of the total outstanding bills. Had Orr gone after 40 companies he would have brought in nearly all the outstanding corporate debt"(Howell 2014).

The National Nurses United union paired up with a conference called Netroots Nation to hold a large rally in Detroit on July 18, 2014. They argued that to withhold water from poor families would create a public health crisis. They suggested that there could be other ways to provide affordable water to poor households. While the rally was underway near the Cobo Center downtown, Bill Wylie-Kellerman and other activists blockaded the main gate of Homrich headquarters on East Grand Boulevard in hopes of delaying trucks of workers heading to shut off people's water. They were arrested (Briscoe and Nichols 2014; Ptashnik and Collier 2014).

Orr has now hired Veolia Water, one of the three largest private water companies in the world, to do an audit and review of the Detroit Water and Sewerage Department [DWSD]. Veolia's supposed purpose is to review finances and staffing of the department and to make recommendations for cost cutting. Shea Howell is concerned that it may lead to Veolia suggesting itself as the manager for the DWSD. The three largest private water companies 
(Germany's RWE-Thames, France's Suez, and Vivendi, now called Veolia, also of France) announced back in 2003 that their goal was to capture seventy percent of the U.S. and Canada's public water utilities. Studies have shown that water quality suffers and prices go up when forprofit companies take charge of municipal water. In 2003 Atlanta canceled its 20-year contract with a subsidiary of Suez after only four years, agreeing to manage its water once again, and Lexington, Kentucky, residents are trying to pass a referendum to free their city from a private water contract (Utne 2006). Recently, Circle of Blue, the journalist organization that collaborates with scientists and other researchers to investigate resources crises, with an emphasis on water use, added Detroit and its water crisis as one of their contemporary foci (Schneider 2014; Parker 2014). The irony of those going without water in the water-rich Great Lakes region, where overall water bills are lower than other areas in the U.S., was summed up in what activist Baxter Jones heard some folks saying: "they should just go to the Detroit river and get their own water”(Parker 2014). Such comments are mean-spirited, says Jones. He has been confined to a wheelchair since a serious auto accident in 2005, but being wheelchair-bound did not stop him from joining others in blockading the entrance to Homrich in an attempt to stop other water shutoffs (Lue 2014; Briscoe and Nichols 2014). Jones is a particularly inspiring example of an activist who looks beyond his personal troubles to join with others to fix a system that could then benefit the entire community. Such determination is alive and well in Detroit.

Activists in the movement to keep water a public utility rather than a private commodity are aware that their struggle is similar to struggles in other parts of our globalized world, as the reach of these multinational water corporations transcends national boundaries. Activists have often taken inspiration from the Bolivian people's movement, often called the Water Wars, in Cochabamba, Bolivia, in late 1999 and early 2000. The newly privatized water company there, 
Aguas del Tunari, owned by Bechtel, raised water prices by 35 percent, setting off protests. The protests were started by campesinos, and then involved factory workers, community residents, women's organizations, and youth. Around this same time, young people in the U.S. were engaged in the "Battle of Seattle," also protesting privatization and the excesses of global capitalism. The people took over Cochabamba's main plaza and occupied it until the government agreed to create a commission that would negotiate terms with Bechtel. But the people went further: in March 2000 they organized a referendum to force Bechtel out of Bolivia. In April they occupied the plaza again, eventually breaking the Bechtel contract and putting the water under municipal control (Goodman 2010).

Wylie-Kellerman and other Detroit water activists like Monica Lewis-Patrick explicitly reference this Bolivia example as proof that it is possible for the city to avoid water privatization, if only people are informed and mobilized. They also see links between Detroiters' struggle to reclaim their city and the Palestinian struggle in Gaza (Bailey 2014). This global exchange of ideas and plans for resistance to privatization has been part of the overall legacy of the global Occupy movement, which spread from Greece in 2008 to Iceland in 2009, to the Spanish indignados in May 2011, and then across to the U.S. later that year. A spokesperson for the Detroit Water Brigade said, "We also look forward to a day when all of Detroit's public services are returned from privatization and mismanagement to full popular control by accountable and democratically elected officials"(Lekas Miller 2014).

\section{Conclusion}

Detroit's fiscal crisis was generated by a complex interplay of factors, including institutional racism and auto industry globalization, which stimulated the departure of businesses and residents from the city. The resulting drop in property values led to further depletion of the city's 
tax revenues, a problem compounded by city subsidies to corporations and investors and the favoritism shown banks in the resolution of the subprime mortgage fiasco. The preferential treatment of big business in questionable deals engineered by Kevyn Orr, the emergency manager appointed by the state's Republican governor, has deepened the crisis at the expense of the citizenry, particularly the most vulnerable populations, the poor and the elderly. Misfortune for such Detroiters, however, spells opportunity for those who have the money to buy up the city's substantial resources at fire-sale prices. Protest against the scandalous mishandling of Detroit's bankruptcy has arisen from many quarters, including local activists, international watchdog groups, journalists, and the United Nations, who argue that the very entities most responsible for the city's woes are among those who will reap the greatest prizes from the Chapter 9 restructuring agreement.

One of the strengths of the protest movement in Detroit is an awareness of the historical context of the city's problems. Protesters see themselves as part of a global resistance movement that seeks to recapture popular control of public resources and place the governance of society in charge of democratically elected, fully accountable entities whose goals privilege human rights and needs rather than private profits. Their success will depend on their ability to build community and devise alternative ways of understanding and living that go beyond self interest and embody a holistic worldview.

\section{References}

Abbey-Lambertz, Kate. 2014. "United Nations Says Turning Off Poor Detroiters' Water Violates Human Rights." Huffington Post, June 26. Retrieved August 30, 2014 (http://www.huffingtonpost.com/2014/06/26/united-nations-detroit-watershutoffs_n_5533901.html). 
Austen, Ben. 2014. "The Post-Post-Apocalyptic Detroit." New York Times Magazine, July 11. Retrieved August 30, 2014 (http://www.nytimes.com/2014/07/13/magazine/the-post-postapocalyptic-detroit.html?_r=1).

Bailey, Kristian. 2014. "Detroit Fights Back: Residents Battle for Water, Democracy and Human Rights.” Ebony, August 19. Retrieved September 8, 2014 (http://www.ebony.com/newsviews/detroit-fights-back-405\#axzz3CVS5fVRc).

Bocian, Debbie Gruenstein, et al. 2011. "Lost Ground, 2011: Disparities in Mortgage Lending and Foreclosures." Center for Responsible Lending. Durham, NC. Retrieved September 9, 2011 (http://www.responsiblelending.org/mortgage-lending/research-analysis/Lost-Ground2011.pdf).

Boggs, Grace Lee. 2011. The Next American Revolution: Sustainable Activism for the TwentyFirst Century. Berkeley: University of California Press.

Bomey, Nathan, and John Gallagher. 2013. "How Detroit Went Broke." Detroit Free Press, September 15. Retrieved August 30, 2014 (http://www.freep.com/interactive/article/20130915/NEWS01/130801004/DetroitBankruptcy-history-1950-debt-pension-revenue).

Briscoe, Tony, and Darren A. Nichols. 2014. "Detroit Water Shut-offs Spark War of Words," Detroit News July 18. Retrieved August 30, 2014 (http://www.detroitnews.com/article/20140718/METRO01/307180043)

Bukowski, Diane. 2014. "Detroit Pastor Removed from Bankruptcy Trial: 'Jones Day is not the City of Detroit!" Voice of Detroit, January 12. Retrieved August 30, 2014 (http://voiceofdetroit.net/2014/01/12/detroit-pastor-removed-from-bankruptcy-trial-jonesday-is-not-the-city-of-detroit/).

Carey, Nick. 2013. "Detroit Bankruptcy Filing Marks New Low for Motor City.” Chicago Tribune, July 18. Retrieved September 8, 2014 (http://www.reuters.com/article/2013/07/18/us-usa-detroit-bankruptcyidUSBRE96H16020130718).

Chaison, Gary. 2014. "The Union's Response to Globalization," SpringerBriefs in Economics 51: 1-18, reference on pp. 1-2.

Conlin, Jennifer. 2011. "Detroit Pushes Back with Young Muscles.” New York Times, July 1. Retrieved September 9, 2014 (http://www.nytimes.com/2011/07/03/fashion/the-young-andentrepreneurial-move-to-downtown-detroit-pushing-its-economicrecovery.html?pagewanted=all\&_r=0).

Ellman, Jeffrey, and Daniel J. Merrett. 2011. "Pensions and Chapter 9: Can Municipalities Use Bankruptcy to Solve Their Pension Woes?" Emory Bankruptcy Developments Journal 27: 365-413. Retrieved August 30, 2014 (http://www.jonesday.com/files/Publication/4ddd9c7ad436-4d0b-b730-2ae65ab8da57/Presentation/PublicationAttachment/0072dbab-09ee-4d8f9a8d-6c6c848bf40f/eReadAttachment.pdf).

Galster, George. 2012. Driving Detroit: The Quest for Respect in the Motor City. Philadelphia: University of Pennsylvania Press.

Goodman, Amy. 2010. “The Cochabamba Water Wars: Marcela Olivera Reflects on the Tenth Anniversary of the Popular Uprising Against Bechtel and the Privatization of the City's Water Supply.” Democracy Now, April 19. Retrieved September 4, 2014 (http://www.democracynow.org/2010/4/19/the_cochabamba_water_wars_marcella_olivera).

Guyette, Curt. 2014. "Anatomy of a Takeover: Examining the Body of Evidence that Emerged in Detroit's Bankruptcy Trial.” Detroit Metro Times, April 2-8, pp. 24-36. 
Hammonds, Don. 2009. "Globalization Brings Flexibility to Auto Industry," Pittsburgh PostGazette Sept. 22. Retrieved September 4, 2009 (http://www.post-gazette.com/news/g20summit/2009/09/22/Globalization-brings-flexibility-to-auto-industry/stories/200909220268).

Howell, Shea. 2014. "Corporate Waters: Week 72 of the Occupation," Michigan Citizen, August 28. Retrieved August 30, 2014 (http://michigancitizen.com/corporate-waters/).

Kiertzner, Jim. 2013. "Protesters at Detroit City Council Meeting." WXYZ-TV news broadcast, April 16. Retrieved September 5, 2013 (https://www.youtube.com/watch?v=J0D694UnCCo).

Lekas Miller, Anna. 2014. "Detroit Activists Herald Partial Victory as City Regains Control of the Water." Truthout August 5. Retrieved September 8, 2014 (http://www.truthout.org/news/item/25381-detroit-activists-herald-partial-victory-as-city-regains-control-ofthe-water).

Lue, Maurielle. 2014. "Ten Arrested During Rally against Detroit Water Shutoffs." WJBK-TV news broadcast, July 11. Retrieved September 8, 2014 (https://www.youtube.com/watch?v=3KOzc6Syndg).

Maithya, Nicholas. 2014 "General Motors Company (NYSE:GM) Experiences Growth of Demand in China." Wall Street PR, September 5. Retrieved September 5, 2014 (http://wallstreetpr.com/general-motors-company-nysegm-experiences-growth-of-demandin-china-30440).

Miller, Chad, and M. Joseph Sirgy. 2011. "The Impact of Globalization of the Automotive Industry on the Quality of Life of the US Southeast," Pp. 145-164 in The Economic Geography of Globalization, edited by Piotr Pachura. Rijeka, Croatia: InTech. Retrieved September 4, 2014 (http://cdn.intechweb.org/pdfs/16922.pdf).

Parker, Aubrey Ann. 2014. "Life Without Water: Voices from Detroit." Circle of Blue. Retrieved August 30, 2014 (http://www.circleofblue.org/waternews/2014/detroit-water-shut-off-actionfigures/reverend-bill-wylie-kellermann/). See esp. quotes by Rev. Bill Wylie-Kellerman and Baxter Jones.

Ptashnik, Ben, and Victoria Collier. 2014. "A National Call to Link Arms for Detroit," The Progressive, July 8. Accessed August 30, 2014 (http://www.progressive.org/news/2014/07/187770/rally-detroit-july-18).

Rugh, Jacob S., and Douglas S. Massey. 2010. "Racial Segregation and the American Foreclosure Crisis." American Sociological Review 75:629-651. doi 10.1177/0003122410380868. Retrieved 9 September 2014 (http://blogs.reuters.com/felixsalmon/files/2010/10/10ASR10_629-651_massey-2.pdf).

Schneider, Keith. 2014. "Detroit Water Shutoffs Resume; Bankruptcy Lawyers and Banks Cash In." Circle of Blue, August 26. Retrieved August 30, 2014

(http://www.circleofblue.org/waternews/2014/world/detroit-water-shutoffs-resumebankruptcy-lawyers-banks-cash/).

Shapiro, Thomas, Tatjana Meschede, and Sam Osoro. 2013. "The Roots of the Widening Racial Wealth Gap: Explaining the Black-White Economic Divide.” Institute on Assets and Social Policy, Research and Policy Brief, February. Waltham, Massachusetts: Brandeis University. Retrieved September 5, 2014 (http://iasp.brandeis.edu/pdfs/Author/shapiro-thomas$\underline{\mathrm{m} / \text { racialwealthgapbrief.pdf). }}$.

Sirota, David. n.d. [2013?] “The Plot Against Pensions.” Institute for America's Future. Washington, DC. Retrieved August 2014 (http://ourfuture.org/wpcontent/uploads/2013/09/Plot-Against-Pensions-final.pdf). 
Sugrue, Thomas. 1996. The Origins of the Urban Crisis: Race and Inequality in Postwar Detroit. Princeton: Princeton University Press, 1996.

Sugrue, Thomas. 2004. "From Motor City to Motor Metropolis: How the Automobile Industry Reshaped Urban America." Automobile in American Life and Society. Retrieved September 5, 2014 (http://www.autolife.umd.umich.edu/Race/R_Overview/R_Overview1.htm).

“True Facts about Emergency Management," 2013. Critical Moment: Detroit by Detroiters, Summer p. 5.

U.S. Department of Commerce. 2005. "U.S. Automotive Industry Employment Trends.” March 30. Retrieved September 4, 2014 (http://trade.gov/static/auto_reports_jobloss.pdf).

Utne, Leif. 2006. "Pandora's Bottle: How Uncapping Your Water Opens the Floodgates to Privatization," Utne Magazine, May/June. Retrieved August 30, 2014 (http://www.utne.com/community/pandorasbottle.aspx\#axzz3C1mtzmR0).

Wikipedia. 2014. "List of General Motors Factories.” Retrieved September 4, 2014 (http://en.wikipedia.org/wiki/List_of_General_Motors_factories) and "List of Chrysler Factories.” Retrieved September 4, 2014 (http://en.wikipedia.org/wiki/List_of_Chrysler_factories).

Woodall, Bernie, and Paul Lienert. 2014. "GM plans To Move Some Chevy Equinox Assembly to Mexico, Report Says," Automotive News August 28. Retrieved September 5, 2014 (http://www.autonews.com/article/20140828/OEM01/140829874/gm-plans-to-move-somechevy-equinox-assembly-to-mexico-report-says).

Wozniak, Gary. n.d. "The Story of Recovery Park: Collaborative Community Development for Detroit." Self Help Addiction Recovery [SHAR] Foundation. Detroit, Michigan. Retrieved September 8, 2014 (http://recoverypark.org/wpcontent/uploads/story\%20of\%20recoverypark.pdf).

Yost, Pete, and Marcy Gordon. 2014. "Bank agrees to Huge Settlement in Mortgage-backed Securities Case," Union-Bulletin [Walla Walla, Washington], August 21. Retrieved August 30, 2014 (http://union-bulletin.com/news/2014/aug/21/bank-agrees-huge-settlementmortgage-backed-securi/). 